\title{
"Enterprise Risk Management and firm performance: an integrated model for the banking sector"
}

\begin{tabular}{|c|c|c|}
\hline \multirow{2}{*}{$\begin{array}{l}\text { AUTHORS } \\
\text { ARTICLE INFO }\end{array}$} & \multicolumn{2}{|l|}{$\begin{array}{l}\text { Alaa Soliman } \\
\text { Mukhtar Adam }\end{array}$} \\
\hline & \multicolumn{2}{|c|}{$\begin{array}{l}\text { Alaa Soliman and Mukhtar Adam (2017). Enterprise Risk Management and firm } \\
\text { performance: an integrated model for the banking sector. Banks and Bank } \\
\text { Systems, } 12(2), 116-123 \text {. doi:10.21511/bbs.12(2).2017.12 }\end{array}$} \\
\hline DOI & \multicolumn{2}{|c|}{ http://dx.doi.org/10.21511/bbs.12(2).2017.12 } \\
\hline RELEASED ON & \multicolumn{2}{|l|}{ Friday, 21 July 2017} \\
\hline RECEIVED ON & \multicolumn{2}{|l|}{ Thursday, 16 February 2017} \\
\hline ACCEPTED ON & \multicolumn{2}{|l|}{ Wednesday, 31 May 2017} \\
\hline LICENSE & \multicolumn{2}{|c|}{$\begin{array}{l}\text { This work is licensed under a Creative Commons Attribution-NonCommercial } 4.0 \\
\text { International License }\end{array}$} \\
\hline JOURNAL & \multicolumn{2}{|l|}{ "Banks and Bank Systems" } \\
\hline ISSN PRINT & \multicolumn{2}{|l|}{$1816-7403$} \\
\hline ISSN ONLINE & \multicolumn{2}{|l|}{$1991-7074$} \\
\hline PUBLISHER & \multicolumn{2}{|c|}{ LLC "Consulting Publishing Company "Business Perspectives" } \\
\hline FOUNDER & \multicolumn{2}{|c|}{ LLC "Consulting Publishing Company "Business Perspectives" } \\
\hline $0^{0}$ & $\circlearrowleft$ & ニ泣 \\
\hline NUMBER OF REFERENCES & NUMBER OF FIGURES & NUMBER OF TABLES \\
\hline 38 & 1 & 6 \\
\hline
\end{tabular}

(c) The author(s) 2023. This publication is an open access article. 
Alaa Soliman (UK), Mukhtar Adam (Nigeria)

\title{
Enterprise Risk Management and firm performance: an integrated model for the banking sector
}

\begin{abstract}
This study investigates how the implementation of Enterprise Risk Management program affects the performance of firms using an Enterprise Risk Management model for the banking sector and an integrated model for measuring Enterprise Risk Management index used in the study by Mukhtar and Soliman (2016). Ten listed commercial banks were selected with the Enterprise Risk Management index as the main independent variable, with Return on Average Equity (ROAE), Share Price Return (SPR) and Firm Value (FV) used as three separate dependent variables. The study provides strong evidence of a positive relationship between Enterprise Risk Management implementation and performance in the Nigerian banking sector. The findings and conclusions of this study are consistent with those of other studies that used data from different industries, providing a basis from which to generalize the findings from this study to firms in other industries.
\end{abstract}

Keywords: ERM, Nigerian banking sector, firm performance.

JEL Classification: G21, G31, G32.

Received on: $16^{\text {th }}$ of February, 2017.

Accepted on: $31^{\text {th }}$ of May, 2017.

\section{Introduction}

Enterprise Risk Management (ERM) as a discipline has received unprecedented interest and international attention in recent years (Arena et al., 2007). The growing interest in ERM has been attributed to a series of challenges in the business world ranging from global financial crises, corporate frauds and scandals, as well as the collapse of major corporate entities (Quon et al., 2012). This has prompted governments, law making bodies, regulators and other stakeholders within the global economic community to explore further insight and understanding of current and emerging risks facing organizations (Paape et al., 2012). A major step taken in this direction is a paradigm shift from silo-based risk management to a holistic approach to risk management commonly known as Enterprise Risk Management (ERM) (Gordon et al., 2009; Hoyt et al., 2010). In this regard, a number of firms have adopted and implemented ERM, rating agencies have integrated ERM analysis into their credit rating processes, regulatory agencies have adopted risk based regulations built on the principles of ERM, and consulting firms have created specialized ERM units (Hoyt et al., 2010).

Justifying the need for more comprehensive and rigorous risk management processes in the Nigerian banking sector, Sanusi (the then Governor of the Central Bank of Nigeria) noted that Nigeria did not feel the full impact of the 2008 global crisis until after the second quarter of 2008, when speculations

\footnotetext{
(c) Alaa Soliman, Mukhtar Adam, 2017.

Alaa Soliman, Dr., Leeds Business School, Leeds Beckett University, UK. Mukhtar Adam, Dr., Zenith Bank, Head Office, Victoria Island, Nigeria.

This is an Open Access article, distributed under the terms of the Creative Commons Attribution-NonCommercial 4.0 International_license, which permits re-use, distribution, and reproduction, provided the materials aren't used for commercial purposes and the original work is properly cited.
}

and uncertainties led to significant divestments from the Nigerian Stock Exchange (NSE) by foreign portfolio managers causing a circa $40 \%$ drop in the market capitalization of the NSE between September 2008 and March 2009 (Sanusi, 2010, p. 6). He pointed out that several measures were adopted by the Nigerian authorities to deal with the crises, including the introduction of more rigorous and comprehensive risk management practices in order to protect banks from the 'bad' experiences of bank failures and past financial crises, especially the 2008 global financial crises.

As Nigerian banks follow the global trend of ERM adoption, the extent to which adopting ERM has affected their performance is not clear. This study seeks to provide empirical evidence on the relationship between ERM and the performance of firms using selected Nigerian banks as the sample for the study. This study connects to previous works of Gordon et al. (2009), Hoyt et al. (2010), Pagach et al. (2010), McShane et al. (2011), Quon et al. (2012), Gates et al. (2012), Baxter et al., (2013), Obalola et al., (2014), Ramlee et al. (2015), and Ping et al. (2015). Previous studies in this research stream (Gordon et al., 2009; Hoyt et al., 2010; Pagach et al., 2010; McShane et al., 2011; Baxter et al., 2013) were largely based on US firms. There are a few studies based on firms from other countries such as UK (Gates et al., 2012), Canada (Quon et al., 2012), Germany (Tekathen et al., 2013), Malaysia (Ramlee et al., 2015; Ping et al., 2015) and Nigeria (Obalola et al., 2014). This study provides more empirical evidence from the Nigerian, African and developing economies perspective and, hence, brings new insights into the generalization of earlier findings in this research stream across different countries and continents. Previously, the only study from Nigeria (Obalola et al., 2014) was based on the 
insurance sector, whereas this study focuses on the banking sector. This study is structured as follows. First, we present the conceptual framework followed by a summary of relevant and related literature on the empirical evidence of the relationship between ERM and performance. We, then, present the methodology and model specification, followed by an analysis of empirical results. Lastly, authors summarize the findings and form conclusion before making recommendations.

\section{ERM and performance}

The major benefit associated with ERM is that, it helps firms to deal with all possible risk effectively and in a coordinated manner, thereby decreasing earnings and stock-price volatility, decreasing cost and increasing efficiency, which ultimately improves the performance and value of firms (COSO, 2004; Beasley et al., 2008; Gordon et al., 2009; Hoyt et al., 2010; Arena et al., 2010; Pagach et al., 2010, 2011; Paape et al., 2012). Highlighting the benefits of ERM to firms, Standard and Poor's (2007) noted that ERM became a differentiating factor among top U.S. insurance firms in the wake of Hurricane Katrina, which occurred in 2005 and costed insurers more than $\$ 41$ billion, the largest ever loss event in the industry. The agency argued that, in their review of credit ratings immediately after the event, insurance firms with stronger ERM processes were able to estimate, within the shortest possible time, their losses, which fell within $25 \%$ of actual claims. They were also able to identify the weak areas in their ERM process and take immediate steps to ratify them, thus, minimizing operational disruptions. The agency further noted that, on the contrary, insurance firms with weaker ERM processes incurred losses of twice what they had previously reported as their "maximum probable loss" and, even, several days after the event, could not reliably estimate their losses.

It is important mention that, implementing an effective ERM has its associated cost. It requires a significant change in the risk management philosophy, culture, business strategy, and internal processes, and technology (Arena et al., 2010; Eckles et al., 2011). This involves direct costs, such as, the cost of acquiring new technology, consultancy cost, training and reorientation cost, and indirect cost such as cost of production or service distraction and change in strategic focus, among others (Dafikpaku, 2011). Also worth mentioning is that, with a firm's investment in ERM implementation, it takes a longer time for the expected benefits to be fully realized, so the immediate benefits of the implementation may not be easily measured in the short term (Pagach et al., 2010; Eckles et al., 2011).
A study by Pagach et al. (2007), examining the stock market reaction to ERM adoption of firms selected across different sectors, found that there was generally no significant stock price reaction (positive or negative) to ERM adoption. In a related study conducted by Beasley et al. (2008), using firms from both financial and non-financial sectors, the researchers tested the hypothesis that a positive correlation exists between certain key performance variables and the adoption of ERM, but found no aggregate significant association between firm performance variables and ERM. Additionally, Pagach et al. (2010) investigated the effects of ERM adoption on long term performance of firms, but found little impact of ERM adoption on a wide range of firm variables, although they found that some firms had experienced a reduction in their earnings volatility, as well as stock returns volatility.

However, another body of literature such as the study by Gordon et al. (2009), which examined the effects of adopting ERM on the performance of firms across different sectors, found a strong positive relation between ERM adoption and firm performance (measured as one year excess stock market returns). In a similar study, Hoyt et al. (2010) investigated how ERM implementation by firms, selected from the banking and insurance sectors, affected their performance. The study found a positive and significant relationship between ERM implementation and firm value (measured by Tobin's Q). Another empirical study which found a positive relationship between ERM implementation and firm performance is the study by Eckles et al. (2011). In this case, using a sample of firms from the insurance sector, which the researchers tested the hypothesis that practicing ERM reduces a firm's cost of risk. The study found that firms adopting ERM experienced a reduction in stock return volatility and an increase in operating profit per unit of risk (Return on Asset - ROA / return volatility). Also, in a related study, McShane et al. (2011) examined the relationship between ERM and firm value using firms selected from the insurance sector and found a positive correlation between ERM and firm value (measured by Tobin's Q). Another study which provided empirical evidence on the benefits of ERM adoption is Baxter et al. (2013). They investigated the association of ERM quality and firm performance and value, using a sample from the banking and insurance sectors, finding strong and positive association between the quality of ERM and financial performance (measured by ROA) and firm value (measured by Tobin's Q). They also found a negative association between ERM quality and stock price volatility, implying that 
the higher the quality of ERM program of a firm, the lower the volatility of its stock price. In another study by Obalola et al. (2014), conducted with samples selected from the Nigerian insurance sector, the researchers examined whether adopting ERM by Nigerian insurance firms could lead to an improvement in their performance, finding significant evidence that adopting ERM, indeed, results in an improvement in the performance of insurance companies in Nigeria. In a more recent study, Ping et al. (2015) examined the impact of implementation of ERM on firm performance of public listed companies in Malaysia and also found significant evidence that firms do experience improvement in performance after adopting ERM.

\section{ERM model for the banking sector}

We acknowledge the presence of several ERM models that provide insights and guidance for ERM implementation and have been used by different firms over the years. In this study, however, we use an ERM model specifically designed for the banking sector, since our study is based on the banking sector. The use of ERM model for the banking sector is critical for this study, because banks' risk management practices have some unique features requiringe more detailed attention. The second reason for using a dedicated ERM model for the banking sector is that, this sector is highly regulated and, therefore, requires an ERM model which meets the minimum regulatory requirements and also creates room to future regulatory directives. Lastly, the banking sector considered to be specialized in several disciplines and for this reasons, is always afforded a certain level of attention. For example, the format of a financial statement for banks is different from those of other industries, with specific accounting and reporting standards set for the banking sector. Based on these justifications for a specialized ERM model for the banking sector, we argue that using an ERM model in this study provides a better basis for measuring and assessing the ERM implementation of banks.

We adopted an ERM model developed by Mukhtar and Soliman (2016) to meet the specific needs of the banking sectors. The model was based on five major themes, namely risk organization and governance, risk insight and strategy, risk process and decisions, operating and regulatory environments, and risk monitoring and reporting. Each of the five major ERM themes has sub-themes providing guidance on what each entails and the details of activities required in meeting the ERM objectives of each thread, as depicted in Figure 1. At the bottom of the sub-themes is a two directional arrow to indicate a continuous interaction among components of the various ERM themes. The main idea is that ERM is not a one-off activity, is rather a continuous process which is monitored, reviewed and updated, where necessary.

\begin{tabular}{|c|c|c|c|c|}
\hline \multicolumn{5}{|c|}{ ERM MODEL FOR THE BANKING SECTOR } \\
\hline $\begin{array}{c}\text { RISK } \\
\text { ORGANIZATION } \\
\text { AND } \\
\text { GOVERNANCE }\end{array}$ & $\begin{array}{c}\text { RISK } \\
\text { INSIGHT AND } \\
\text { STRATEGY }\end{array}$ & $\begin{array}{c}\text { RISK PROCESS } \\
\text { AND } \\
\text { DECISIONS }\end{array}$ & $\begin{array}{c}\text { OPERATING } \\
\text { AND } \\
\text { REGULATORY } \\
\text { ENVIRONMEN }\end{array}$ & $\begin{array}{c}\text { RISK } \\
\text { MONITORING } \\
\text { AND } \\
\text { REPORTING }\end{array}$ \\
\hline $\begin{array}{l}\text { - Defining risk philosophy } \\
\text { and strategy } \\
\text { - Creating risk } \\
\text { management culture } \\
\text { - Board involvement in } \\
\text { risk management } \\
\text { - Alignment of risk } \\
\text { management with } \\
\text { corporate strategy } \\
\text { - Organizational structure } \\
\text { - Interaction of risk } \\
\text { management functions } \\
\text { with other organizational } \\
\text { functions }\end{array}$ & $\begin{array}{l}\text { - Analysis of risk- } \\
\text { return trade-off } \\
\text { - Stree testing and } \\
\text { alignment of risk } \\
\text { assessment } \\
\text { - Risk IT and data } \\
\text { infrastructure } \\
\text { - Development of } \\
\text { risk appetite } \\
\text { statement } \\
\text { - Strategy for } \\
\text { planning and } \\
\text { decision making }\end{array}$ & $\begin{array}{l}\text { - Planning, budget } \\
\text { and budgetary } \\
\text { controls } \\
\text { - Performance } \\
\text { management and } \\
\text { performance based } \\
\text { incentive } \\
\text { - Internal control } \\
\text { functions } \\
\text { - Risk } \\
\text { identification, } \\
\text { measurement and } \\
\text { monitoring } \\
\text { - Risk operations } \\
\text { and mitigation }\end{array}$ & $\begin{array}{l}\text { - Competitive } \\
\text { environment } \\
\text { - Economic } \\
\text { environment } \\
\text { - Compliance } \\
\text { with relevant } \\
\text { laws and } \\
\text { regulations } \\
\text { - Compliance } \\
\text { with golabl } \\
\text { best practices }\end{array}$ & $\begin{array}{l}\text { - On-going risk } \\
\text { monitoring } \\
\text { - Periodic risk } \\
\text { monitoring } \\
\text { - Loss } \\
\text { forecasting and } \\
\text { provisioning } \\
\text { - Risk } \\
\text { communication } \\
\text { and reporting }\end{array}$ \\
\hline
\end{tabular}

Fig. 1. ERM model for the banking sector 


\section{Integrated model for measuring ERM implan- tation for the banking sector}

In this study, we adopt two models that are specific to the banking sector to facilitate ERM measurement. The integration of these two models for ERM measurement was first suggested by Mukhtar and Soliman (2016) as a way of addressing the serious limitations associated with ERM measurements. The first ERM model used in the integrated model was specifically designed for the banking sector with the relateds to the 'CAMELS' models for assessing the soundness of banks. The 'CAMELS' model for determining the financial soundness indicators of financial institutions was first proposed in 1988 by the Basel Committee on Banking Supervision (BCBS) of the Bank for International Settlements (BIS) as a five-component model "CAMEL" and updated with the sixth component for what we currently have as 'CAMELS' (Dash and Das, 2013). According to $\mathrm{BCBS}$, the essence of the model is to provide financial institutions with a tailored model that will assist them in monitoring and managing the most important risk they face and, at the same time, measuring their performance on those indicators.

Using these two models which are specifically designed for the banking sector, unable us to elicit more critical banking performance measures than a general ERM and performance measure model. Secondly, for an efficient interaction of the two models to produce one ERM measure, both models must be compatible, in the sense that both must aim at driving and measuring the same sets of objectives. The integrated ERM measurement model was anchored on the basis that the effects of a bank's undertaking the activities relating to each of the ERM themes become manifest in certain financial and non-financial performance indicators or measures. These financial and nonfinancial performance measures are, in turn, directly or indirectly captured by the various components of the CAMELS model. Therefore, the integration produced a matrix that comprised of five ERM themes on the horizontal side and the six components of 'CAMELS' on the vertical side. On the matrix, the points of intersection of an ERM theme and a component of the 'CAMELS' model represent a set of outcomes that result from carrying out ERM related activities. Such outcomes also translate into prudential indicators that represent the CAMELS components. Finally, important financial performance measures, in the form of prudential indicators, and nonfinancial performance measures, in the form qualitative measures for each cell of the matrix, were integrated to form an ERM index used in the empirical section of this study.

\section{Model specification}

For estimation purposes, we used the following multiple linear regression models:

$R O A E ; S P R ; F V=\beta_{0}+\beta_{1} E R M$ index $+\beta_{2}$ Size $+\beta_{3}$ Systemic risk $+\beta_{4}$ Leverage $+\beta_{5}$ Growth opportunities $+\beta_{6}$ Institution $+\varepsilon$,

where $R O A E ; S P R ; F V=$ the dependent variables; $\beta_{0}$ $=$ the regression constant; $\beta_{1}-\beta_{7}=$ variable coefficients; $\varepsilon=$ the error term.

In equation 1 , we used each of the dependent variables (ROAE, SPR and FV) separately to run the model, thereby producing three different regression models with same independent and controlled variables but different dependent variables (Hoyt et al., 2010; McShane et al., 2011; Gates et al., 2012).

In running the regression model, we are interested in obtaining the coefficient of multiple correlations which helps to measure the degree of linear association between the dependent and all the explanatory variables jointly. We also focus on the multiple coefficient of determination (R-squared) which indicates the proportion or percentage of the total variation in the dependent variable explained by the independent and controlled variables, in addition to the adjusted Rsquared', which provides the same information as Rsquared, but with implicit adjustments for the explanatory variables in the model (Gujarati et al., 2010a).

To test whether the explanatory variables explain zero percent of the variation in the dependent variable, we use the test of the overall significance of estimated multiple regression. In this test, we adopt the hypothesis that all the explanatory variables are jointly insignificant, in other words, all the explanatory variables together have no influence on the dependent variable. The alternative hypothesis is that at least one of the explanatory variables explains the variation in the dependent variables.

$$
\begin{array}{lll}
H_{0}: \beta_{1}=\beta_{2}=\beta_{3} \ldots \ldots \beta_{8} & \text { or } & H_{0}: R^{2}=0 \\
H_{0}: \beta_{1} \neq \beta_{2} \neq \beta_{3} \ldots \ldots \beta_{8} & \text { or } & H_{0}: R^{2} \neq 0
\end{array}
$$

\section{Discussion of empirical results}

We present the results of regression models run using the Ordinary Least Square (OLS) method. We run three regressions with ROAE, SPR and FV as the dependent variable in each of the regressions, with the same independent variables (ERM index ERMI) and five control variables [log of total assets - LOG(TA), beta - BT, leverage - LRG, revenue growth - RVG and log of institutional effect LOG(INST)]. Prior to running each of the regression models, diagnostic analyses of the regressions were conducted to ascertain the extent to which the model exhibits qualities of good regression model. 
5.1. Regression model 1: regression analysis with Return on Average Equity (ROAE) as dependent variable with ERM index and controlled variables as regressors. The results of the regression model 1 summarized in Table 2 show positive coefficients for ERMI, revenue growth (RVG) and institutional effect (OG INST), which means that these three variables are positively related to ROAE, consistent with our theoretical expectation. The remaining three variables, total assets (LOG TA), beta (BT) and leverage (LRG), have negative coefficients, which means that they are all negatively related to ROAE. The negative relationship between ROAE on one side, and beta and leverage on another side is also consistent with our theoretical expectation.

With regard to the sign of the variable coefficient of total assets (LOG TA), it contradicts our theoretical expectation in the sense that, generally, the ability of a firm to generate more revenue, which is subsequently translated into higher returns, is largely influenced by the amount of assets or investments at the disposal of the firm. This general expectation of a positive relationship between returns (ROAE) and total assets will not hold in the case, where assets available are not efficiently deployed to generate desired revenue or in the case where operating costs are unnecessarily high due to operational inefficiencies. We, therefore, note the contradiction of our expected relationship between ROAE and total asset, as a reflection of the disparities between asset size of our sampled banks and profitability levels.

Table 1. Summary of results of residual diagnostic test for regression model 1

\begin{tabular}{|l|c|c|c|}
\hline & $\begin{array}{c}\text { Breusch- } \\
\text { Godfrey }\end{array}$ & $\begin{array}{c}\text { Breusch-Pagan- } \\
\text { Godfrey test }\end{array}$ & $\begin{array}{c}\text { Histogram } \\
\text { Normality test' }\end{array}$ \\
\hline Observed R-squared & 2.623304 & 4.997331 & \\
\hline P-value & 0.1053 & 0.5442 & \\
\hline Jarque-Bera & & & 0.136949 \\
\hline P-value & & & 0.933817 \\
\hline
\end{tabular}

Table 2. OLS - regression model 1

\begin{tabular}{|l|c|c|c|}
\hline \multicolumn{4}{|c|}{ Dependent variable: ROAE } \\
\hline \multicolumn{1}{|c|}{ Variable } & Coefficient & t-statistic & p-value \\
\hline Intercept & 1.502526 & 3.352395 & 0.0440 \\
\hline ERMI & 0.320444 & 3.377694 & 0.0432 \\
\hline LOG(TA) & -0.124508 & -3.564955 & 0.0377 \\
\hline BT & -0.230465 & -3.347835 & 0.0441 \\
\hline LRG & -0.141043 & -3.921383 & 0.0295 \\
\hline RVG & 0.068953 & 0.814557 & 0.4750 \\
\hline LOG(INST) & 0.250139 & 2.895704 & 0.0627 \\
\hline R-squared & 0.971666 & & \\
\hline Adjusted R-squared & 0.914997 & & \\
\hline F-statistic & 17.14648 & & \\
\hline Prob. (F-statistic) & 0.020164 & & \\
\hline
\end{tabular}

Based on the above analyses we can conclude that there is a significant positive relationship between ROAE and ERMI. We can also conclude that our regression model is statistically good enough to be used for forecasting.

5.2. Regression model 2: regression analysis with Share Price Return (SPR) as dependent variable. The regression model 2 provided some useful insights into the relationship between SPR and ERMI alongside other controlled variables. First of all, the regression model provided significant positive relationship between SPR and ERM but failed to provide significant evidence of the relationship between SPR and any of the individual controlled variables (total assets - LOG TA, beta - BT, leverage - LRG, revenue growth - RVG and institutional effect - LOG INST). Secondly, we obtained evidence from the regression model to the effect that the explanatory variables in the regression are statistically jointly significant, in addition to the evidence that variation in the dependent variable is significantly explained by the explanatory variables. One exception noted from the result of the regression equation estimate is that five out of the six explanatory variables are not individually significant, which reduces the 'goodness fit' of the regression model, as a 'good fit' regression model should have at least half of the explanatory variables individually significant. The second exception noted is that the coefficient of one controlled variable (LOG TA- total asset) contradicts our theoretical expectation of the positive relationship between the dependent variable (SPR) and total assets.

Table 3. Diagnostic tests for regression model 2

\begin{tabular}{|l|c|c|c|}
\hline & $\begin{array}{c}\text { Breusch- } \\
\text { Godfrey }\end{array}$ & $\begin{array}{c}\text { Breusch-Pagan- } \\
\text { Godfrey test }\end{array}$ & $\begin{array}{c}\text { Histogram } \\
\text { Normality test' }\end{array}$ \\
\hline Observed R-squared & 0.404890 & 5.983573 & \\
\hline P-value & 0.5246 & 0.4250 & \\
\hline Jarque-Bera & & & 0.434281 \\
\hline P-value & & & 0.804817 \\
\hline
\end{tabular}

Table 4. OLS - regression model 2

\begin{tabular}{|l|r|r|l|}
\hline \multicolumn{5}{|c|}{ Dependent variable: SPR } \\
\hline \multicolumn{1}{|c|}{ Variable } & \multicolumn{1}{c|}{ Coefficient } & t-statistic & p-value \\
\hline Intercept & 3.296552 & 1.790765 & 0.1713 \\
\hline ERMI & 1.360178 & 3.490672 & 0.0397 \\
\hline LOG(TA) & -0.334630 & -2.332738 & 0.1019 \\
\hline BT & -0.201932 & -0.714181 & 0.5267 \\
\hline LRG & -0.171494 & -1.160866 & 0.3297 \\
\hline RVG & 0.306866 & 0.882604 & 0.4424 \\
\hline LOG(INST) & 0.371310 & 1.046537 & 0.3722 \\
\hline R-squared & 0.959528 & & \\
\hline Adjusted R-squared & 0.878583 & & \\
\hline F-statistic & 11.85411 & & \\
\hline Prob. (F-statistic) & 0.033917 & & \\
\hline
\end{tabular}


Interestingly, the regression residuals diagnostics provided positive results in the sense that the regression residuals were found not to have serial correlation or heteroscedasticity and are normally distributed. Based on the analyses above, we therefore conclude that there is a significant positive relationship between SPR and ERMI and that our regression model 2 is statistically reasonably fit except for the exceptions noted.

\subsection{Regression model 3: regression analysis with} Firm Value (FV) as dependent variable. The results of regression model 3 provided some interesting findings, as opposed to the results of regression models 1 and 2. In the first place, athough ERMI was found to be positively related to FV as expected, the relationship was not significant. Based on further analysis, we argue that this interesting outcome was influenced by the consistent unexpected behavior of total asset as a controlled variable in the regression models. Secondly, out of the six explanatory variables in the regression model 3, four (ERMI, beta BT, leverage - LRG and institutional effect - LOG INST) exhibited their theoretical expectation with the dependent variable (FV), while the remaining two (total assets - LOG TA and revenue growth - RVG) did not meet our theoretical expectation of their relationship with FV. Also, four of the explanatory variables were found to be individually significant and all the explanatory variables were equally found to be jointly significant to FV. Our diagnostics of the regression residuals revealed that the regression residuals do not have serial correlation or heteroscedasticity and are normally distributed.

We also note that ERMI failed to be significant to FV (though indicated positive relationship), as opposed to regression models 1 and 2, partly due to the information that influenced FV. In determining the dependent variables, we used Tobin's Q as a proxy to FV and adopted the definition of Cummins et al. (2006) (cited in Hoyt et al., 2010), which expressed Tobin's Q as the market value of equity plus the book value of liabilities divided by the book value of assets. A critical review of the results of the regressions shows that total assets (LOG TA) has consistently thrown up exception in terms of its expected relationship with other variables in the regression model.

Generally, total assets are expected to be positively related to performance, return on average equity (ROAE), share price return (SPR) and firm value (FV). In our regression analysis, however, total assets (LOG TA) has consistently come out to be negatively related to these performance parameters and other variables in the regression that are expected to move in the same direction as total assets. Our detailed analysis of the data set collected for this study shows some disparities between the asset base and performance levels of our sampled banks. Such disparities point to the fact that, as far as our data set is concerned, the assets base of banks does not always reflect their performance levels. In which case, banks with a higher assets base that is not efficiently utilized, could have lower performance (absolute or relative) when compared to banks with lower, but efficiently utilized assets.

Relating this exceptional behavior of assets to the FV obtained from our data set, we note that, since total asset is the denominator in our formula for Tobin's Q (our proxy for FV), the higher the value of an asset, the lower the firm (FV) value, all other things being equal. From the results of regression models 1 and 2, ERMI as the main independent variable was found to be positively related and significant (individually and jointly with other variables) to the dependent variables (ROAE and SPR). In those regression models, total asset (LOG TA) was found to be negatively related to ROAE and SPR. Since total asset in our data set has consistently contradicted its expected behavior, we argue that the unexpected behavior of total asset in our data set is responsible for exerting an influence on FV to cause it not to have significant relationship with ERMI when other performance measures (ROAE and SPR) from the same data set have significant relationship with ERMI.

Table 5. Summary of results of residual diagnostic test for regression model 3

\begin{tabular}{|l|c|c|c|}
\hline & $\begin{array}{c}\text { Breusch- } \\
\text { Godfrey }\end{array}$ & $\begin{array}{c}\text { Breusch-Pagan- } \\
\text { Godfrey test }\end{array}$ & $\begin{array}{c}\text { Histogram } \\
\text { Normality test' }\end{array}$ \\
\hline Observed R-squared & 1.763087 & 6.673770 & \\
\hline P-value & 0.1842 & 0.3521 & \\
\hline Jarque-Bera & & & 0.293000 \\
\hline P-value & & & 0.863726 \\
\hline
\end{tabular}

Table 6. Summary of results of Ordinary Least Square Regression - regression model 3

\begin{tabular}{|l|c|c|c|}
\hline \multicolumn{4}{|c|}{ Dependent variable: FV } \\
\hline \multicolumn{1}{|c|}{ Variable } & Coefficient & t-statistic & p-value \\
\hline Intercept & 5.067201 & 12.85562 & 0.0010 \\
\hline ERMI & 0.162810 & 1.951376 & 0.1461 \\
\hline LOG(TA) & -0.331968 & -10.80795 & 0.0017 \\
\hline BT & -0.520881 & -8.603772 & 0.0033 \\
\hline LRG & -0.252292 & -7.975954 & 0.0041 \\
\hline RVG & -0.143202 & -1.923595 & 0.1501 \\
\hline LOG(INST) & 0.780845 & 10.27848 & 0.0020 \\
\hline R-squared & 0.986402 & & \\
\hline Adjusted R-squared & 0.959206 & & \\
\hline F-statistic & 36.27024 & & \\
\hline Prob. (F-statistic) & 0.006825 & & \\
\hline
\end{tabular}

\section{Conclusion}

In this study, we find significant evidence of positive relationship between ERM and the performance of Nigerian banks. This implies that, from our data, 
banks with high ERM ratings performed better than banks with low ERM ratings. These findings can also be interpreted to mean that firms that adopt ERM perform better than firms that have not adopted ERM. In the same vein, we can interpret the findings in terms of the extent of ERM implementation by positing that firms that are advanced in their ERM implementation performed better than those at foundation stage. This finding is consistent with the theoretical expectation of the benefits of ERM adoption or implementation to firms as confirmed by COSO (2004), Beasley et al. (2008), Gordon et al. (2009), Hoyt et al. (2010), Arena et al. (2010), Pagach et al. (2010, 2011), Paape et al. (2012). The evidence of positive relationship between ERM and performance of Nigerian banks obtained from this study is equally consistent with the empirical findings of Andersen (2008), Gordon et al. (2009), Hoyt et al. (2010), Eckles et al. (2011), McShane et al. (2011), Baxter et al. (2013), Ping et al. (2015).

On the other hand, the evidence of significant positive relationship between ERM and firm performance provided by this study contradicts evidences from other empirical studies. For example, in a study by Pagach et al. (2007), which examined the stock market reaction to ERM adoption of firms, the researc- hers found no significant stock price reaction (positive or negative) to ERM adoption. In a similar study by Beasley et al. (2008), in which the researchers tested the hypothesis that a positive correlation exists between certain key performances variables and the adoption of ERM, the study failed to find aggregate significant association between firm performance and ERM. In, yet, another study by Quon et al. (2012), the researchers examined how ERM implementation affected selected financial performance measures of firms, but failed to find significant evidence of any association between ERM implementation and financial performance. In a more recent study, Ramlee et al. (2015) compared the relationship between ERM implementation and performance of firms, but failed to obtain significant evidence of any relationship. Theoretically, Tekathen et al. (2013) have argued that the postulated benefits of ERM are only theoretical in nature, as firms do not, in practice, necessarily enjoy such benefits as attributed by promoters of ERM.

Based on this study and considering the evidences provided by several studies on the effect of ERM on performance, we conclude that the adoption of ERM, indeed, provides some benefits to firms including improvement in performance measures such as ROAE, SPR and FV.

\section{References}

1. Andersen, T. (2008). The Performance Relationship of Effective Risk Management: Exploring the Firm-Specific Investment Rationale. Long Range Planning, 41(2), 155-176.

2. Agusto and Agusto \& Co Research. (2010). Banking Industry Report, Lagos. Agusto \& Co. Ltd.

3. Agusto and Agusto \& Co Research. (2013). Banking Industry Report, Lagos. Agusto \& Co. Ltd.

4. Agusto and Agusto \& Co Research. (2014). Banking Industry Report, Lagos. Agusto \& Co. Ltd.

5. Arena, M., Arnaboldi, M., and Azzone, G. (2010). The organizational dynamics of enterprise risk management. Accounting, Organizations and Society, 35(7), 659-675.

6. Baxter, R., Bedard, J. C., Hoitash, R., and Yezegel, A. (2013). Enterprise risk management program quality: Determinants, value relevance, and the financial crisis. Contemporary Accounting Research, 30(4), 1264-1295.

7. Beasley, M. S., Clune, R., and Hermanson, D. R. (2005b). Enterprise risk management: An empirical analysis of factors associated with the extent of implementation. Journal of Accounting and Public Policy, 24(6), 521-531.

8. Beasley, M., Pagach, D., and Warr, R. (2008). Information conveyed in hiring announcements of senior executives overseeing enterprise-wide risk management processes. Journal of Accounting, Auditing Finance, 23(3), 311-332.

9. Campbell, D. (2008). Nonfinancial Performance Measures and Promotion-Based Incentives. Journal of Accounting Research, 46(2), 297-332.

10. Central Bank of Nigeria. (2010d). Regulation on the Scope of Banking Activities and Ancillary Matters. 3(2010), Abuja, Nigeria.

11. Central Bank of Nigeria. (2013). Bank Intermediation in Nigeria: Growth, Competition, and Performance of The Banking Industry, 1990-2010, Abuja, Nigeria.

12. Committee of Sponsoring Organisations of the Treadway Commission. (2004). Enterprise Risk Management (ERM) COSO Framework. Retrieved from http://www.sox online.com/coso_2004_coso_framework.html

13. Dafikpaku, E. (2011). The Strategic Implications of Enterprise Risk Management: A Framework. Paper presented at ERM Symposium. Retrieved from http://www.ermsymposium.org/2011/pdf/Dafikpaku.pdf

14. Dash, M., and Das, A. (2013). Performance Appraisal of Indian Banks Using CAMELS Rating. The IUP Journal of Bank Management, 12(2), 31-42.

15. Eckles, D., Hoyt, R., and Miller, S. (2011). The Impact of Enterprise Risk Management on the Marginal Cost of Reducing Risk: Evidence from the Insurance Industry. Social sciences Research Network.

16. Flamini, V., McDonald, C., and Schumacher, L. (2009). The Determinants of Commercial Bank Profitability in Sub-Saharan Africa. IMF Working Paper (WP/09/15).

17. Francis, M. E. (2013). Determinants of Commercial Bank Profitability in Sub-Saharan Africa. International Journal of Economics and Finance, 5(9), 67-79.

18. Gates, S., Nicolas, J., and Walker, P. (2012). Enterprise Risk Management: A Process for Enhanced Management 
and Improved Performance. Management Accounting Quarterly. Spring 2012, 13(3), 28-38.

19. Gordon, L., Loeba, M., and Tseng, C. (2009). Enterprise risk management and firm performance: A contingency perspective. Journal of Accounting and Public Policy, 28(4), 301-327.

20. Greuning, H., and Brajovic Bratanovic, S. (2009). Analyzing banking risk. Washington, D.C.: World Bank.

21. Gujarati, D. N., and Porter, D. C. (2010a). Essentials of Econometrics, Fourth edition. New York: McGraw-Hill International Edition.

22. Gujarati, D. N. (2010b). Econometrics by Example. Macmillan Publishers, London.

23. Hoyt, R., and Liebenberg, A. (2010). The Value of Enterprise Risk Management. Journal of Risk and Insurance, $4(1), 123-145$.

24. Koch, T. W., and MacDonald, S. S. (2010). Bank Management, Seventh edition. South Western Cengage Learning, Mason Ohio.

25. McShane, M., Nair, A., and Rustambekov, E. (2011). Does enterprise risk management increase firm value? Journal of Accounting, Auditing and Finance, 26(4), 641-658.

26. Obalola, M. A., Akpan, T. I., and Abass, O. A. (2014). The Relationship between Enterprise Risk Management (ERM) and Organizational Performance: Evidence from Nigerian Insurance Industry. Research Journal of Finance and Accounting, 5(14).

27. Ongore, V. O., and Kusa, G. B. (2013). Determinants of Financial Performance of Commercial Banks in Kenya. International Journal of Economics and Financial Issues, 3(1), 237-252.

28. Paape, L., and Spekle, R. F. (2012). The adoption and design of enterprise risk management practices: An empirical study. European Accounting Review, 21(3), 533-564.

29. Pagach, D., and Warr, R. (2007). An Empirical Investigation of the Characteristics of Firms Adopting Enterprise Risk Management. Retrieved from http://www.ermsymposium.org/pdf/papers/Pagach.pdf

30. Pagach, D. and Warr, R. (2010). The Effects of Enterprise Risk Management on Firm Performance”. Social sciences Research Network. Retrieved from http://papers.ssrn.com/sol3/papers.cfm?abstract_id=1155218

31. Pagach, D., and Warr, R. (2011). The characteristics of firms that hire chief risk officers. Journal of Risk and Insurance, $78(1), 185-211$.

32. Ping, T. A., and Muthuveloo, R. (2015). The Impact of Enterprise Risk Management on Firm Performance: Evidence from Malaysia. Asian Social Science, 11(22), 1911-2025.

33. Quon, T., Zeghal, D., and Maingot, M. (2012). Enterprise Risk Management and Firm Performance. Procedia Social and Behavioural Sciences, 62(2), 263-267.

34. Ramlee, R., and Ahmad, N. (2015). Panel Data Analysis on the Effect of Establishing the Enterprise Risk Management on Firms' Performances. 4th European Business Research Conference 9 - 10 April 2015, Imperial College, London, UK.

35. Sanusi, S. (2010). Global Financial Crises Impact in Nigeria, Nigerian Financial Reforms and the Roles of Multilateral Development Banks and IMF. Submission to the House Financial Services Committee of the US Congress Hearing on the Global Financial Crisis. [report].

36. Central Bank of Nigeria. Retrieved from http://financialservices.house.gov/media/ file/hearings/111/sanusi111610.pdf

37. Standard \& Poor's. (2007). Request for comment: Enterprise risk management analysis for credit ratings of nonfinancial companies. Retrieved from http://www.rims.org/resources/ERM_OLD/Documents/ ERM_ratingspracticesSandP.pdf

38. Tekathen, M., and Dechow, N. (2013). Enterprise risk management and continuous realignment in the pursuit of accountability: A German case. Management Accounting Research, 24(2), 100-121. 